\title{
Bilateral Congenital Diaphragmatic Hernia: A Rare Case Report
}

\author{
Elif Ăgaçayak*, Mehmet Özer**, Abdulkadir Turgut*, \\ Ali Özler*, Senem Yaman Tunç**
}

(*) Department of Gynecology and Obstetrics, Dicle University Faculty of Medicine, Diyarbakır

(**) Department of Pediatric Surgery, Genesis Hospital, Diyarbakır

\begin{abstract}
Congenital diaphragmatic hernia is a relatively rare birth defect with unknown etiology. Its association with other anomalies and distinct clinical patterns suggest that several causes may be involved. Congenital diaphragmatic hernia occurs in 1 in 2500 live births. In $85 \%$ of cases the defect is left-sided [1]. Most cases of congenital diaphragmatic herniaare sporadic and familial congenital diaphragmatic herniais rare, comprising only $2 \%$ of congenital diaphragmatic herniacases[2]. Thiscongenital anomaly can almost always be recognized with prenatal ultrasound screening. There is a high degree of variability in both treatment and outcomes. Bilateral congenital diaphragmatic hernia is a rare birth defect, with grim prognosis. We describe a case of bilateral congenital diaphragmatic hernia discovered while repartitioning right sided congenital diaphragmatic hernia. The diaphragmatic defect was repaired and a prolene mesh was placed on the abdominal wound to avoid abdominal compartment syndrome. The patient nonetheless died post operatively due to severe pulmonary hypertension. Bilateral congenital diaphragmatic hernia, priorly identified through a limited number of case reports, is extremely rare. The care of congenital diaphragmatic hernia patients is very difficult for neonatologists and surgeons. Our report particularly the management and outcome of patients with bilateral congenital diaphragmatic hernia.
\end{abstract}

Keywords: Bilateral congenital diaphragmatic hernia, Pulmonary hypertension.

\footnotetext{
Iletişim Bilgileri:

Sorumlu Yazar: Elif $A \breve{G} A C ̧ A Y A K$

Yazışma Adresi: Dept. of Gynecology and Obstetrics, Dicle Unv. Faculty of Medicine, Diyarbakır, TÜRKIYE

Tel: +904122488001 Gsm: +905059433449

Email: drelifagacayak@gmail.com

Makalenin Geliş Tarihi: 09/09/2013

Makalenin Kabul Tarihi: 10/12/2013
}

\author{
Bilateral Konjenital Diyafragmatik Herni: Nadir Bir \\ Olgu
}

ÖZET

Konjenital diyafragma hernisi nedeni bilinmeyen, oldukça nadir görülen bir doğumsal anomalidir. Diğer anomaliler ile ilişkisi ve farklı klinik desenleri ile çeşitli nedenleri olabileceğini düşündürmektedir. Konjenital diyafragma hernisi 2.500 canlı doğumda 1 görülür. Olguların\% 85'inde defekt [1] sol taraflıdır. Konjenital diyafragma hernisi vakalarının çoğu sporadiktir. Ailesel konjenital diyafragma hernisi, tüm vakaların sadece $\% 2$ “ sini [2] oluşturur, oldukça nadirdir. Bu konjenital anomali hemen hemen her zaman doğum öncesi ultrasonografik muayene ile tanınabilir. Tedavisi ile sonuçlar herninin derecesine göre değişkenlik gösterir. Bilateral konjenital diyafragma hernisi kötü prognozile, nadir bir doğumsal anomalidir. Biz sağ taraflı konjenital diyafragma hernisi operasyon sırasında keşfedilen bilateral konjenital diyafragma hernisi olgusu sunulmuştur. Diyafragmatik defekt onarıldı ve bir prolen örgü abdominal kompartman sendromu önlemek için karın yara yerleştirildi. Hasta yine de ameliyat sonrası ciddi pulmoner hipertansiyon nedeniyle öldü. Öncelikle olgu sınırlı sayıda olup bilateral konjenital diyafragma hernisi, son derece nadirdir. CDH hasta bakımı yenidoğan ve cerrahlar için çok zordur. Olgumuzu sunmamızın amacı özellikle bilateral konjenital diyafragma hernisi olan hastaların tedavi ve sonuçlarını değerlendirmektir.

Anahtar Kelimeler: Bilateralkonjenitaldiyafragmahernisi, Pulmoner hipertansiyon. 


\section{INTRODUCTION}

Congenital diaphragmatic hernia( $\mathrm{CDH}$ ) occurs in every 2500-3000 live births [1-3]. Bilateral $\mathrm{CDH}$ is extremely rare, comprising less than $1 \%$ of all $\mathrm{CDH}$ cases [4]. Most of them die in utero while less than $35 \%$ survive [ $1-5]$. The administration of bilateral CDH is a challenge for pediatric surgeons and the neonatologists. We report a case of bilateral $\mathrm{CDH}$ with sac on both sides. and discuss the literature.

\section{CASE REPORT}

The patient was admitted to our clinic with15th gestational week ultrasound revealed the stomach in the thorax next to the fetal heart (Figure 1).

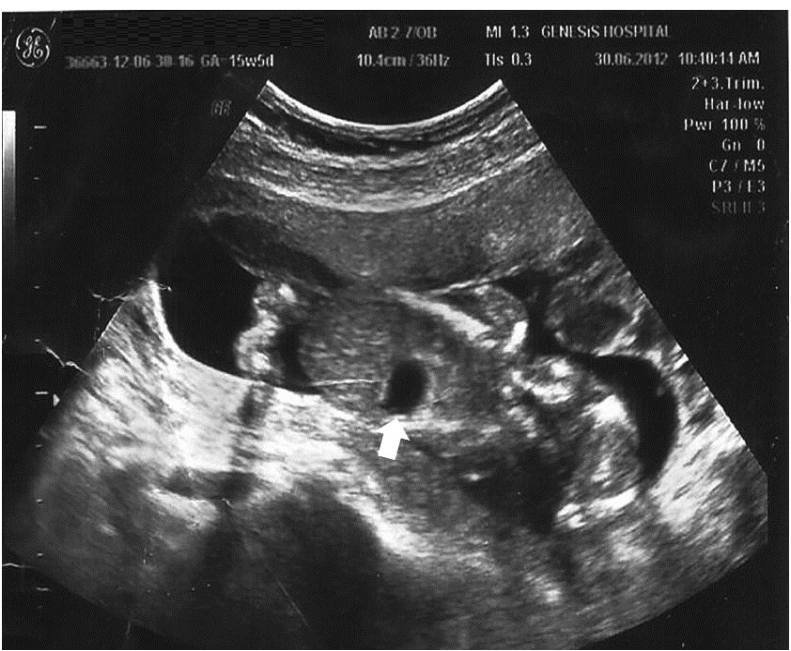

Figure 1: 15 th pregnancy week diaphragmatic hernia image

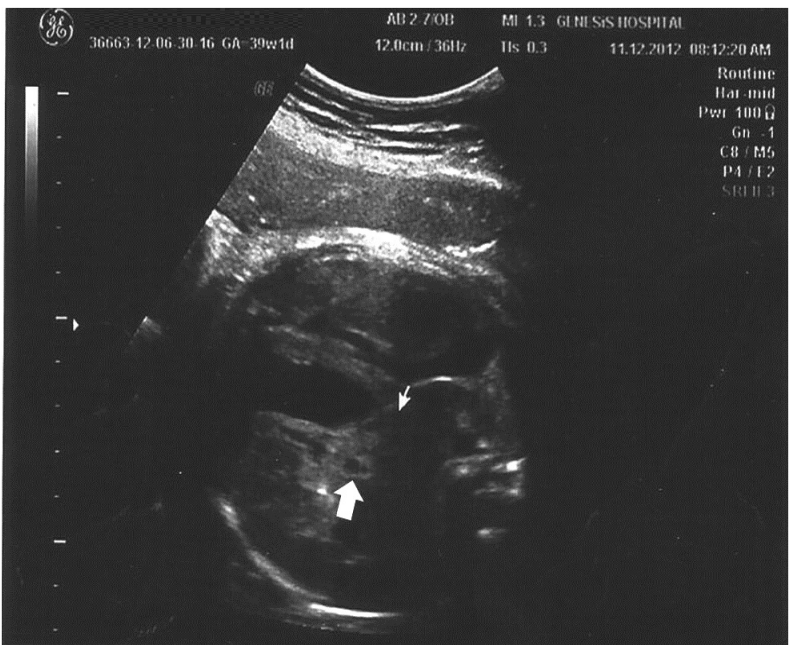

Figure 2: 36 th pregnancy week diaphragmatic hernia image

The family was informed. Advancedultrasound was performed and demonstrated bilateral diaphragmatic hernia. At the 29th gestational week, the patient was reinspected and the fetal heart was deviated to the right. Growthretarda- tion was present in the fetus. At the 36th week, the heart of the fetus was severely deviated to the right. The left lobe of the liver was viewed in the thorax (Figure 2). The fetus had severe growth retardation. The patient was called for weekly visits. The risks were explained to the family on week 39 and cesearean section was performed. The baby had birth asphyxia and was resuscitated with bag and mask ventilation. He was a 2600 grams male fetus with APGAR scores 5 and 4 at the first and fifth minutes, respectively. The patient was kept in the intensive care unit under oxygen and feeds were started.On admission his respiratory rate was $70 / \mathrm{min}, \mathrm{SpO}_{2}$ was $87 \%$ while receiving oxygen. Chest X-ray observed in both lungs collapsed (Figure 3).

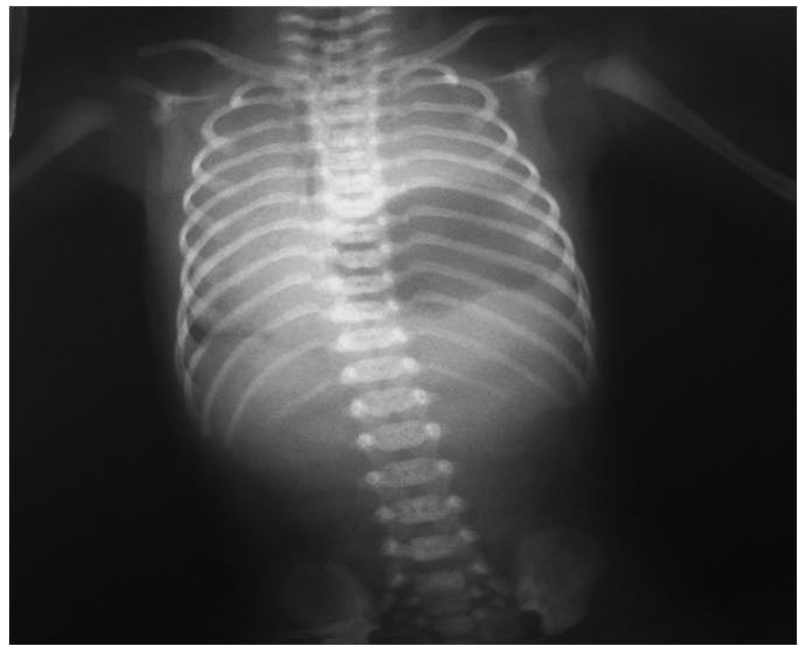

Figure 3: Preoperative chest radiograph

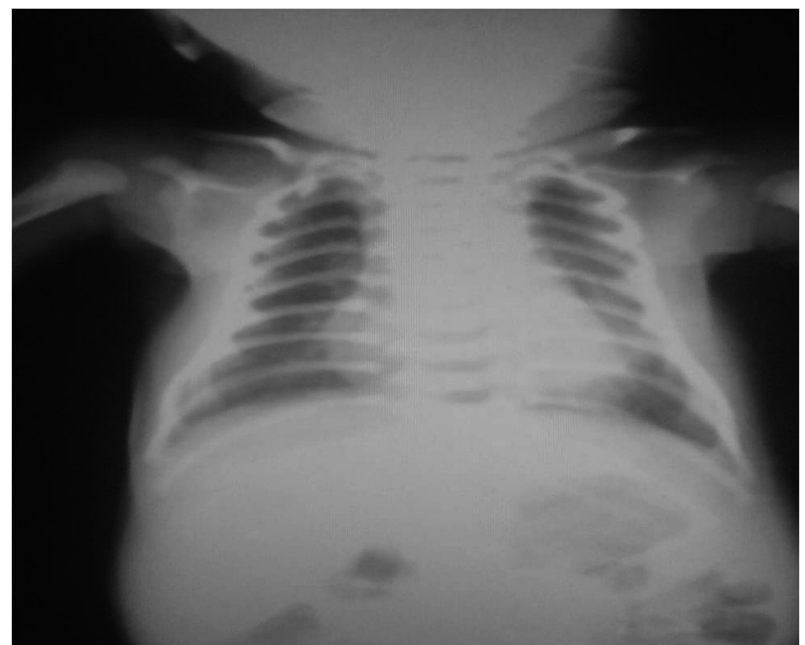

Figure 4: Postoperative chest radiograph

The fetus under went urgent surgical operation. The thorax was entered via left subcostalincision. Spleen, stomach, small intestine, left lobe of the liver and the leftcolon were observed in the thorax. The organs were with drawn from the abdominal cavity and a bilateral wide diaphragmatic hernia was observed. A chest $-27-$ 
tube was applied to the left thorax. Underwater drain age was performed. Half of the primary and lateral half of the defect was closed using prolene mesh. The newborn had intestinal mal rotation which was closed in accordance with the anatomy of the abdomen. Postoperatively the baby was electively ventilated at rates of 40 per minute and $\mathrm{FiO}_{2}$ of $85 \%$. The patient, however, deteriorated and developed advanced severe pulmonary hypertension. Although the lung was moderately expanded on a postoperative chest radiograph (Fig. 4), the child went into refractory shock and died 56 hours after surgery.

\section{DISCUSSION}

The prognosis of CDH is mainly determined by the degree of pulmonary hypoplasia. $\mathrm{CDH}$ including the neonatal period is mostly of the Bochdalek type. The defect is usually unilateral and involves the left diaphragm in $75 \%$ of cases [ 6]. Conversely, bilateral $\mathrm{CDH}$ is rare and usually fatal. Right-sided defects with delayed diagnoses may cause a wide spectrum of clinical signs [ 4 ]. Delayed presentation of right-sided $\mathrm{CDH}$ in association with neonatal group B streptococcalp neumonia is a well-recognizedentity [ 4-5 ]. Antenatal diagnosis of $\mathrm{CDH}$ is relatively easy and the sonographic signs of unilateral $\mathrm{CDH}$ are mediastinal shift, presence of intestine in the thorax, small abdominal circumference and polyhydramnios suffice[1-10 ]. Mediastinal shift is often the first abnormality observed. In our case the diagnosis was made during week 15 th. Song et al[2] recorded antenatal finding of bilateral $\mathrm{CDH}$ in a fetus and concluded that bilateral diaphragmatic hernia should be suspected when the degree of mediastinal shift is less than that guessed for a unilateral hernia in existence of other features of $\mathrm{CDH}$.

An identifiable cause is present in about $15-20 \%$ of individuals with diaphragm defects [6] . A chromosome abnormality is present in about $10 \%$ of all individuals with $\mathrm{CDH}$. The most common abnormalities are trisomy 18 and tetrasomy $12 \mathrm{p}$ (Pallister-Killian syndrome). Many additional abnormalities have been reported, such as trisomy 21 , trisomy 13 , tetrasomy 21, trisomy 8 and other structural abnormalities. Small rearrangements found in unrelated individuals have suggested that one or more genes significant for normal diaphragm development may reside in critical regions such as $15 \mathrm{q} 26.2$ [ 6-10]. In a study made by Furuta et al [3] reported the 11th recorded case of bilateral $\mathrm{CDH}$. The patient was lost in the postoperative period after repair of right $\mathrm{CDH}$ while the left side CDH was identified at autopsy. Our case was detected at week 15 since the patient came for her first visit at this time. The intrauterine diagnosis was confirmed during operation of the newborn. We favored an abdominal approach since part of the liver had herniated through a large defect in the diaphragm.Another advantage of the abdominal approach is that a prolene mesh can be used. In a study made by Kufeji and Crabbe reported familial $\mathrm{CDH}$ in twosiblings with a similar type of bilateral CDH in 1999 [7]. Both cases could not be diagnosed antenatally and their outcomes were severe. In a study made by 2003 Neville et al retrospectively reviewed cases of $\mathrm{CDH}$ treated in 83 different hospitals in USA.

They found that in bilateral CDH mortality rate was $65 \%$ compared with $33 \%$ of patients with unilateral $\mathrm{CDH}$ [ 8]. In contrast, reports of patients with favorable outcome have also been published in literature. In 2007 Zaupa et al recorded a case of bilateral CDH with gastroschisis with good out-come [ 9]. They suggested that a low intrathoracic pressure due to gastroschisis may have been allowed for good lung development and better patient outcome.In our case although the preoperative stabilization was well, there was severe pulmonary hypertension that led to the mortal outcome. In conclusion, although early diagnosis and early intervention was under taken in our patient, the bilateral hernia remained mortal.

\section{CONCLUSION}

The management of infants with bilateral congenital diaphragmatic hernia remains a difficult problem with significant mortality. Compared to unilateral $\mathrm{CDH}$, bilateral congenital diaphragmatic hernia is more frequently associated with other major anomalies and should immediate further evaluation. 


\section{REFERENCES}

1. Pober BR, Lin A, Russell M et al. 2005. Infants with Bochdalek diaphragmatic hernia sibling precurrence and monozygotic twin discordance in a hospital-based mal formation surveillance program. Am J MedGenet A138A:81-88

2. Song MS, Yoo SJ, Smallhorn JF, Mullen JB, Ryan G, Hornberger LK. Bilateral congenital diaphragmatic hernia: diagnostic clues at fetal sonography. Ultrasound Obstet Gynecol. 2001; 17: 255-8.

3. .Furuta Y, Nakamura Y, Miyamoto K. Bilateral congenital postero lateral diaphragmatic hernia. J Pediatr Surg. 1987; 22: 182- 3.

4. Glüer S, vonSchweinitz D. Delayed presentation of a right-sided diaphragmatic hernia following necrotizing enter ocolitis: casereport. Pediatr SurgInt 1997; 12 (1) 59-60

5. Jandus P, Savioz D, Purek L, Frey JG, Schnyder JM, Tschopp JM. Bochdalek hernia: a rare cause of dyspnea and abdominal pain in adults. RevMedSuisse. 2009; 5: 1061- 4 .
6. Poenaru D, Laberge J, Jéquier S, Blanchard P, Doody D. Ultrasound diagnosis of delayed-on set congenital diaphragmatic hernia associated with group B streptococcal infection. Pediatr SurgInt 1988; 3: 66-69.

7. Kufeji DI, Crabbe DC. Familial bilateral congenital diaphragmatic hernia. Pediatr SurgInt. 1999; 15: $58-60$

8. Neville HL, Jaksic T, Wilson JM, Lally PA, Hardin WD Jr, Hirschl RB, et al. Bilateral congenital diaphragmatic hernia. J Pediatr Surg. 2003; 38: $522-4$

9. Zaupa P, Kleinlein B, Höllwarth ME. Bilateral congenital diaphragmatic hernia and gastroschisis in a newborn: can low intrathoracic pressure preventth epulmonary hypoplasia? Pediatr SurgInt. 2007; 23: 711-3.

10.Anjan kumar Dhua, Satish K Aggarwal, NB Mathur, and GR Sethi Bilateral Congenital Diaphragmatic Hernia APSP J Case Rep. 2012 Sep-Dec; 3(3): 20 